JPdK Volume 2 No1 Tahun 2020 Halaman 27-33

JURNAL PENDIDIKAN dan KONSELING

UNIVERSITAS

Research \& Learning in Primary Education

\title{
Keterampilan Saintifik Anak Kelompok A Pada Permainan Sains Di Sentra Bahan Alam RA Baiturrahman
}

\author{
Eka Sutisnawati ${ }^{1}$, Edi Hendri Mulyana ${ }^{2}$ Sumardi $^{3}$ \\ Program Pendidikan Guru Pendidikan Anak Usia Dini \\ Fakultas Ilmu Pendidikan \\ Universitas Pendidikan Indonesia Kampus Tasikmalaya \\ Email: ekasutisnawati23@gmail.com
}

\begin{abstract}
Penelitian ini bertujuan untuk mendeskripsikan dan menganalisis Keterampilan Saintifik Anak Kelompok A pada Permainan Sains di Sentra Bahan Alam RA Baiturrahman dengan menggunakan metode penelitian deskriptif kuantitatif.Sampel yang digunakan dalam penelitian ini berjumlah 6 anak. Alat pengumpulan data pada penelitian ini adalah observasi dan dokumentasi. Hasil temuan penelitian ini dinyatakan bahwa 1) Kinerja guru mengelola sentra bahan alam dalam permainan sains dengan hasil pencapian terendah $10 \%$. Artinya guru cukup baik mengelola sentra bahan alam dalam permainan sains, dan hasil pencapaian tertinggi yaitu $90 \%$. Artinya guru sangat baik mengelola sentra bahan alam dalam permainan sains. Maka rata-rata dari kinerja guru mengelola sentra bahan alam dalam permainan sains yaitu sangat baik. 2) Kinerja guru mengelola permainan sains yang terdiri dari permainan sains gunung meletus, water filter (penyaringan air kotor menjadi air bersih), dan listrik statis terdapat pencapaian dengan hasil tertinggi $100 \%$ atau dapat diartikan pencapaian sangat baik. Rata-rata dari kinerja guru mengelola permainan sains yaitu sangat baik. 3) Keterampilan saintifik kelompok A pada permainan sains gunung meletus, water filter (penyaringan air kotor menjadai air bersih), dan listrik statis. Dari ketiga permainan sains tersebut diperoleh hasil pencapaian terendah yaitu $20 \%$ anak memiliki keterampilan saintifik Berkembang Sangat Baik (BSB), dan pencapian tertinggi 80\% anak memiliki keterampilan saintifik Berkembang Sesuai Harapan (BSH). Maka rata-rata keterampilan saintifik anak kelompok A pada permainan sains yaitu cukup baik atau Berkembang Sesuai Harapan (BSH).
\end{abstract}

Kata Kunci : Keterampilan Saintifik, Permainan Sains, Sentra Bahan Alam

\begin{abstract}
This study aims to describe and analyze the Scientific Skills of Group A Children in Science Games at RA Baiturrahman's Natural Materials Center by using quantitative descriptive research methods. The sample used in this study amounted to 6 children. The data collection tool in this study is observation and documentation. The findings of this study stated that 1) The performance of the teacher manages the centers of natural materials in science games with the lowest attenuation results of $10 \%$. This means that the teacher is quite good at managing the centers of natural materials in science games, and the highest achievement results are $90 \%$. This means that the teacher is very good at managing centers of natural materials in science games. So the average performance of teachers managing natural materials centers in science games is very good. 2) Performance of teachers managing science games consisting of erupting mountain science games, water filters (filtering dirty water into clean water), and static electricity there are achievements with the highest results of $100 \%$ or can be interpreted as achieving very well. The average performance of teachers managing science games is very good. 3) Group A scientific skills in erupting mountain science games, water filters (filtering dirty water to clean water), and static electricity. Of the three science games, the lowest achievement results were obtained, namely $20 \%$ of children had
\end{abstract}


Very Good Evolving Scientific Skills (BSB), and the highest ignition was 80\% of children had Evolving Scientific Skills according to Expectation (BSH). Then the average scientific skills of children in group A in science games are quite good or developing according to expectations (BSH).

Keywords: Scientific Skills, Science Games, Natural Materials Centers

\section{PENDAHULUAN}

Anak usia dini yaitu anak umur 0-6 tahun. Pada masa ini anak memiliki potensi yang masih harus dikembangkan, karena karakteristik anak berbeda dengan orang dewasa, anak bersifat aktif dan selalu ingin tahu apa yang dilihat, didengar dan dirasakan olehnya. Sehubungan dengan ini,Peraturan Pemerintah Republik Indonesia No. 17 Tahun 2010 yang dimaksudkan dengan pendidikan anak usia dini adalah suatu upaya pembinaan yang ditujukan kepada anak sejak lahir sampai dengan usia 6 (enam) tahun yang dilakukan melalui pemberian rangsangan pendidikan untuk membantu pertumbuhan dan perkembangan jasmani dan rohani agar anak memiliki kesiapan dalam memasuki pendidikan lebih lanjut

Mengacu pada kurikulum terbaru yaitu kurikulum 2013, proses pembelajaran di setiap jenjang pendidikan dilaksanakan secara tematik integratif. Dalam kurikulum PAUD ada suatu pendekatan/keterampilan, yaitu pendekatan saintifik yang memungkinkan peserta didik belajar secara efektif dan bermakna. Pendekatan saintifik merupakan suatu pendekatan ilmiah. Menurut Kurikulum PAUD tahun 2013 menyatakan bahwa "Pendekatan saintifik adalah proses pembelajaran yang dirancang sedemikian rupa agar peserta didik secara aktif membangun kompetensi sikap, pengetahuan, dan keterampilan melalui tahapan mengamati, menanya, mengumpulkan informasi, menalar, dan mengomunikasikan.”

Pendidikan bagi anak usia dini adalah belajar sambil bermain dan bermain seraya belajar. Dengan bermain anak dapat berekspresi dan bereksplorasi dalam menemukan hal-hal yang baru. Dengan demikian, guru harus membuat pembelajaran yang menyanangkan dan bermakna untuk anak usia dini. Berhubungan dengan ini Agustin (2017, hlm. 3) mengemukakan bahwa "Belajar yang menyenagkan dan bermakna akan memberikan dampak psikologis positif kepada anak didik. Anak didik yang mendapatkan perlakuan positif dari gurunya akan semakin semangat dan bergairah dalam belajar".
Pembelajaran yang menyenangkan yaitu pembelajaran sains, pada pembelajaran sains anak mempunyai rasa ingin tahu yang tinggi. Sejalan dengan ini Siti (2018, hlm.5) mengemukakan bahwa "Permainan sains pada anak usia dini merupakan kegiatan belajar yang menyenangkan dan menarik yang dilaksanakan sambil bermain melalui pengamatan, penyelidikan, dan percobaan untuk mencari tahu atau menemukan jawaban tentang kenyataan yang ada di dunia sekitar".

Pembelajaran yang menyenangkan untuk anak usia dini efektif dilaksanakan dengan metode pembelajaran sentra. Model pembelajaran sentra adalah model pembelajaran yang melihat kemampuan setiap anak dari tolak ukur kemapuan klasifikasi yang dibangun melalui serangkaian aktivitas yang menggunakan benda-benda (mainan) konkret. Di RA Baiturrahman terdapat 9 sentra yaitu: sentra balok, sentra bermain peran, sentra kreativitas, sentra bahan alam, sentra iptek, sentra musik, sentra olah tubuh, sentra imtaq, sentra memasak. Pada peneliatian ini peneliti menggunakan sentra bahan alam. Peneliti memilih model pembelajaran sentra bahan alam dianggap relevan dalam memfasilitasi anak untuk mengembangkan dan memperluas pengalaman bermain sensorimotor dengan mengeksplorasi bahan-bahan alami (daun, ranting, kayu, biji-bijian, air, pasir, batu, dan lain-lainnya), sehingga dapat mengembangkan motorik halus anak.

Berdasarkan uraian diatas penulis melakukan penelitian keterampilan saintifik anak kelompok A pada permainan sains di sentra bahan alam RA Baiturrahman. Penelitian ini dibatasi pada lingkup penelitian Deskriptif Kuantitatif dengan judul :Keterampilan Saintifik AnakKelompok A pada Permainan Sains di Sentra Bahan Alam RA Baiturrahman. Undang-Undang RI No. 20 Tahun 2003 tentang Sistem Pendidikan Nasional menyatakan bahwa :

Pendidikan anak usia dini adalah suatu upaya pembinaan yang ditujukan kepada anak sejak lahir sampai dengan usia enam tahun yang dilakukan melaui pemberian rangsangan 
pendidikan untuk membantu pertumbuhan dan perkembangan jasmani dan rohani agar anak memiliki kesiapan dalam memasuki pendidikan lebih lanjut. Sejalan dengan ini, Sujiono (2013, hlm. 90) berpendapat bahwa

Pendidikan hendaknya mengarahkan anak untuk menjadi pembelajar yang aktif. Pembelajaran yang dirancang secara kreatif dan menghasilkan pembelajaran yang aktif. Anak-anak akan terbiasa belajar dan mempelajari berbagai aspek pengetahuan, keterampilan, dan kemampuan melalui berbagai aktivitas mengamati, mencari, menemukan, mendiskusikan, menyimpulkan dan mengemukakan sendiri berbagai hal yang ditemukan pada lingkungan sekitar.

Permendikbud tahun 2013 (dalam panduan pendidikan kurikulum 2013 paud anak usia 4-5 tahun, 2014, hlm. 18) mengemukakan bahwa "Pendekatan saintifik adalah proses pembelajaran yang dirancang sedemikian rupa agar peserta didik secara aktif membangun kompetensi sikap, pengetahuan dan keterampilan dengan menggunakan pendekatan ilmiah".

Berdasarkan pengertian daiatas dapat disimpulkan bahwa pendekatan saintifik adalah untuk memberikan pemahaman kepada peserta didik dalam mengenal, memahami berbagai materi menggunakan pendekatan ilmiah, bahwa informasi bisa berasal dari mana saja, kapan saja, tidak tergantung pada informasi searah dari guru. Oleh karena itu, kondisi pembelajaran yang diharapkan tercipta diarahkan untuk mendorong peserta didik dalam mencari tahu dari berbagai sumber melalui observasi, dan bukan hanya diberi tahu. Langkahlangkah Pendekatan Saintifik antara lain : 1) Mengamati, 2) Menanya, 3) Mengumpulkan informasi, 4) Menalar/mengasosiasi 5) Mengomunikasikan. Namun, pada penelitian ini peneliti hanya memfokuskan tiga pendekatan saintifik yaitu : 1) Mengamati, 2) Menanya, dan 3) Mengomunikasikan.

Pendekatan saintifik sangat baik diajarkan kepada anak sejak usia dini, agar anak terlatih berpikir secara saintifik dan memudahkan anak dalam proses penguasaan konsep materi yang mereka peroleh. Pembelajaran pada anak usia dini adalah belajar sambil bermain, berhubungan dengan ini Sujiono (2013, hlm. 145) "Bermain memiliki tujuan utama yakni memelihara perkembangan atau pertumbuhan optimal anak usia dini melalui pendekatan bermain yang kreatif, dan terintegrasi dengan lingkungan bermain anak".

Pembelajaran pada anak usia dini yaitu belajar sambil bermain. Permainan dalam pembelajaran anak usia dini adalah permainan yang dapat mengembangkan aspek kognitif pada anak atau anak dapat memecahkan suatu masalah. Seperti permainan sains, pada permainan sains anak dapat berekspresi, berkreasi, dan berpikir kritis. Permainan sains adalah suatu kegiatan pembelajaran atau pengenalan sains yang di sesuaikan dengan karakteristik anak usia dini, dimana proses penyampaiannya dilakukan berdasarkan prinsip-prinsip bermain (sebagai salah satu jenis dari konsep bermain). Prinsip-prinsip bermain tersebut diantaranya : sesuai dengan tahapan perkembangan anak, berorientasi pada kebutuhan anak, bermain sambil belajar, bersifat aktif, kreatif, inovatif, efektif, dan menyenangkan.

Suyanto (2005, hlm. 159) mengemukakan bahwa "Pengenalan sains untuk anak usia dini dilakukan untuk mengembangkan kemampuan berikut: 1) Eksplorasi dan investigasi, yaitu kegiatan untuk mengamati dan menyelidiki objek dan fenomena alam. 2) Mengembangkan keterampilan proses sains dasar, seperti melakukan pengamatan, mengukur, menggunakan bilangan, dan mengkomunikasikan hasil pengamatan. 3) Mengembangkan rasa ingin tahu, rasa senang, dan mau melakukan kegiatan inkuiri dan penemuan. 4) Memahami pengetahuan tentang berbagai benda, baik ciri, struktur, maupun fungsinya".

Nugraha, Ali (2008, hlm. 27-29) mengemukakan bahwa "Tujuan-tujuan pengajaran sains bagi anak memiliki 3 dimensi utama sebagai sasaran pokoknya, yaitu dimensi produk, dimensi proses, dan dimensi sikap sains". Adapun macammacam permainan sains untuk anak usia dini yang dapat dikembangkan di sentra bahan alam sebagai berikut: 1) Gunung Meletus, 2) Water Filter (Penyaringan Air Kotor Menjadi Air Bersih), dan 3)Listrik Statis.

Permainan sains ini dapat efektif di laksanakan dengan metode pembelajaran sentra. Sentra disebut juga dengan area, sudut kegiatan (activity centre), sudut belajar (learning centre) atau sudut minat (interest centre). Mukhtar Latif, dkk (2013, hlm.132) mengemukakan bahwa "Sentra bahan alam adalah sentra yang memberikan kesempatan kepada anak-anak untuk berinteraksi langsung dengan berbagai macam 
bahan untuk mendukung sensomotorik, self control, dan sains". Sedangkan menurut Suyadi dan Dahlia (2014, hlm. 50) "Sentra bahan alam adalah bermaksud memberikan kesempatan kepada anak bereksplorasi dengan berbagai bahan yang ada di alam. Kegiatan yang bisa dilakukan adalah dengan mencampur warna, memancing, meronce, dan menempel biji-bijian".

\section{HASIL PENELITIAN DAN PEMBAHASAN}

Penelitian ini bertujuan untuk mendeskripsikan keterampilan saintifik anak kelompok A pada permainan sains di sentra bahan alam RA Baiturrahman. Pendekatan penelitian yang digunakan penelititi adalah pendekatan kuantitatif. Creswell (2013, hlm. 5) mengemukakan bahwa "Penelitian kuantitatif merupakan metode-metode untuk menguji teoriteori tertentu dengan cara meneliti hubungan antar variabel. Variabel-variabel ini diukur biasanya dengan instrumen penelitian sehingga data yang terdiri dari angka-angka dapat dianalisis berdasarkan prosedur-prosedur statistik". Metode penelitian deskriptif dengan pendekatan kuantitatif, dapat digunakan peneliti untuk mengumpulkan data, mengolah data, menganalisis, dan memecahkan sebuah masalah yang bertujuan untuk mendapatkan kesimpulan dari suatu keadaan yang lengkap danakurat mengenai keterampilan saintifik anak kelompok A2 pada permainan sains di sentra bahan alam RA Baiturrahman.

Berdasarkan hasil penelitian yang telah dilakukan, sebelum memulai melakukan penelitian peneliti mempersiapkan RPPH (Rangangan Pelaksanaan Pembelajaran Harian) yang disesuaikan dengan tema serta mencakup indikator yang sesuai dengan perkembangan atau kebutuhan anak, menyiapkan ruangan, mempersiapkan media berkenaan dengan kegiatan yang akan dilakukan dan berkenaan dengan sentra bahan alam.

1. Kinerja guru mengelola sentra bahan alam, dari hasil pengolahan data mengenai kinerja guru mengelola sentra bahan alam dalam permainan sains sangat baik. Berikut ini dijelaskan kinerja guru dalam permainan sains berdasarkan masingmasing permainan sains.

a. Kinerja guru mengelola sentra bahan alam dalam permainan sains gunung meletus. Berdasarkan hasil pengolahan data, kinerja guru dalam permainan sains gunung meletus, pada indikator 1 diperoleh data 4 ketercapaian sudah mencapai ketercapaian Sangat Baik (SB). Indikator 2 terdapat 3 ketercapaian sudah mencapai ketercapaian Baik (B). Indikator 3 terdapat 3 ketercapaian sudah mencapai ketercapaian Baik (B). Dari data tersebut dapat dilihat bahwa kinerja guru mengelola sentra bahan alam dalam permainan sains gunung meletus sangat baik. Hal ini dapat dibuktikan dengan banyaknya ketercapaian gurumengelola sentra bahan alam dalam permainan sains gunung meletus baik.

b. Kinerja guru mengelola sentra bahan alam dalam permainan sains water filter (penyaringan air kotor menjadi air bersih). Berdasarkan hasil pengolahan data, kinerja guru mengelola sentra bahan alam dalam permainan sains water filter (penyaringan air kotor menjadi air bersih). Berdasarkan hasil pengolahan data, kinerja guru dalam permainan sains gunung meletus, pada indikator 1 diperoleh data 4 ketercapaian sudah mencapai ketercapaian Sangat Baik (SB). Indikator 2 terdapat 4 ketercapaian sudah mencapai ketercapaian Sangat Baik (SB). Indikator 3 terdapat 3 ketercapaian sudah mencapai ketercapaian Baik (B). Dari data tersebut dapat dilihat bahwa kinerja guru mengelola sentra bahan alam dalam permainan sains water filter (penyaringan air kotor menjadi air bersih) sangat baik. Hal ini dapat dibuktikan dengan banyaknya ketercapaian gurumengelola sentra bahan alam dalam permainan sains water 
filter (penyaringan air kotor menjadi air bersih) sangat baik.

c. Kinerja guru mengeloala sentra bahan alam dalam permainan sains listrik statis. Berdasarkan hasil pengolahan data, kinerja guru meneglola sentra bahan alam dalam permainan sains listrik statis, pada indikator 1 diperoleh data 4 ketercapaian sudah mencapai ketercapaian Sangat Baik (SB). Indikator 2 terdapat 4 ketercapaian sudah mencapai ketercapaian Sangat Baik (SB). Indikator 3 terdapat 3 ketercapaian sudah mencapai ketercapaian Baik (B). Dari data tersebut dapat dilihat bahwa kinerja guru mengelola sentra bahan alam dalam permainan sains listrik statis sangat baik. Hal ini dapat dibuktikan dengan banyaknya ketercapaian gurumengelola sentra bahan alam dalam permainan sains listrik statis sangat baik.

2. Kinerja guru mengelola permainan sains. Kinerja guru pada penelitian ini yaitu guru mempasilitasi anak untuk mengamati, mempasilitasi anak untuk menanya, mempasilitasi anak untuk memngumpulkan informasi, dan lain sebaginya agar anak mendapatkan hasil belajar dengan baik. Dari hasil pengolahan data mengenai kinerja guru mengelola permainan sains sangat baik. Berikut ini dijelaskan kinerja guru mengelola permainan sains berdasarkan masingmasing permainan sains.

a. Kinerja guru mengelola permainan sains gunung meletus. Berdasarkan hasil pengolahan data, kinerja guru mengelola permainan sains gunung meletus, pada indikator 1 diperoleh data sebagai berikut : terdapat 3 ketercapaian sudah mencapai ketercapaian Baik (B). Indikator 2 terdapat 4 ketercapaian sudah mencapai ketercapaian Sangat Baik (SB). Indikator 3 terdapat 4 ketercapaian sudah mencapai ketercapaian Sangat Baik (SB). Indikator 3terdapat 4 ketercapaian Sanagt Baik (SB). Indikator 5 terdapat 4 ketercapaian Sangat Baik (SB). Dan pada indikator 6 terdapat 3 ketercapaian Baik (B)Dari data tersebut dapat dilihat bahwa kinerja guru mengelola permainan sains gunung meletus sangat baik. Hal ini dapat dibuktikan dengan banyaknya ketercapaian guru dalam mengelola permainan sains sangat baik.

b. Kinerja guru mengelola permainan sains water filter (penyaringan air kotor menjadi air bersih). Berdasarkan hasil pengolahan data, kinerja guru mengelola permainan sains gunung meletus, pada indikator 1 diperoleh data sebagai berikut : terdapat 4 ketercapaian sudah mencapai ketercapaian Sangat Baik (SB). Indikator 2 terdapat 4 ketercapaian sudah mencapai ketercapaian Sangat Baik (SB). Indikator 3 terdapat 4 ketercapaian sudah mencapai ketercapaian Sangat Baik (SB). Indikator 3terdapat 4 ketercapaian Sanagt Baik (SB). Indikator 5 terdapat 3 ketercapaian Baik (B). Dan pada indikator 6 terdapat 3 ketercapaian Baik (B). Dari data tersebut dapat dilihat bahwa kinerja guru mengelola permainan sains water filter (penyaringan air kotor menjadi air bersih) sangat baik. Hal ini dapat dibuktikan dengan banyaknya ketercapaian guru dalam mengelola permainan sains sangat baik.

c. Kinerja guru mengelola permainan sains listrik statis. Berdasarkan hasil pengolahan data, kinerja guru mengelola 
permainan sains listrik statis, pada indikator 1 diperoleh data sebagai berikut : terdapat 4 ketercapaian sudah mencapai ketercapaian Sangat Baik (SB). Indikator 2 terdapat 4 ketercapaian sudah mencapai ketercapaian SangatBaik (SB). Indikator 3 terdapat 4 ketercapaian sudah mencapai ketercapaian Sangat Baik (SB). Indikator 3terdapat 4 ketercapaian Sanagt Baik (SB).

3. Keterampilan saintifik anak kelompok A. Keterampilan saintifik anak usia kelompok A diperoleh melalui hasil penelitian. Pada penelitian ini peneliti hanya menggunakan 3 keterampilan saintifik yaitu keterampilan saintifik 1) mengamati, 2) menanya dan 3) mengumpulkan informasi. Berdasarkan hasil pengolahan data mengenai keterampilan saintifik anak kelompok A2 pada permainan sains gunung meletus sebanyak 5 anak dengan kriteria pencapaian Berkembang Sesuai Harapan (BSH) dan 1 anak dengan kategori kor maksimal yang diperoleh anak yaitu 3 dengan kategori berkembang Sesuai Harapan (BSH). Dari perolehan data skor keterampilan saintifik anak kelompok A2 pada permainan sains gunung meletus, water filter (penyaringan air kotor menjadi air bersih), dan listrik statis yang banyak diperoleh anak yaitu skor 3. anak-anak kelompok A2 di RA Baiturrahman sebanyak 90\% keterampilan saintifik dalam permainan sains sudah berkembang sesuai harapan.

\section{SIMPULAN}

(1) Kinerja guru mengelola sentra bahan alam dalam permainan sains dengan hasil pencapian terendah $10 \%$. Artinya guru cukup baik mengelola sentra bahan alam dalam permainan sains, dan hasil pencapaian tertinggi yaitu $90 \%$. Artinya guru sangat baik mengelola sentra bahan alam dalam permainan sains. Maka rata-rata dari kinerja guru mengelola sentra bahan alam dalam permainan sains yaitu sangat baik.

\begin{tabular}{llrr} 
Indikator & 5 & terdapat & 3 \\
ketercapaian & Baik & (B). Dan pada \\
indikator & 6 & terdapat & 3 \\
ketercapaian & Baik & (B). Dari data \\
tersebut dapat & dilihat & bahwa \\
kinerja & guru & \multicolumn{2}{c}{ mengelola } \\
permainan & sains listrik & statis \\
sangat baik. Hal ini & dapat \\
dibuktikan & dengan banyaknya \\
ketercapaian & guru & dalam \\
mengelola & permainan & sains \\
sangat & & & baik.
\end{tabular}

pencapaian berkembang Sangat Baik (BSB). Keterampilan saintifik anak kelompok A2 pada permainan sains water filter (penyaringan air kotor menjadi air bersih) sebanyak 4 anak dengan kriteria berkembang sangat baik (BSB) dan 2 anak dengan kriteria berkembang sesuai harapan (BSH). Sedangkan keterampilan saintifik anak kelompok A2 pada permainan sains listrik statis sebanyak 2 anak dengan kriteria pencapaian berkembang sangat baik (BSB) dan 4 anak dengan kategori pencapian berkembang sesuai harapan (BSH).

(2) Kinerja guru mengelola permainan sains yang terdiri dari permainan sains gunung meletus, water filter (penyaringan air kotor menjadi air bersih), dan listrik statis terdapat pencapaian dengan hasil tertinggi $100 \%$ atau dapat diartikan pencapaian sangat baik. Ratarata dari kinerja guru mengelola permainan sains yaitu sangat baik.

(3) Keterampilan saintifik kelompok A pada permainan sains gunung meletus, water filter (penyaringan air kotor menjadai air bersih), dan listrik statis. Dari ketiga permainan sains tersebut diperoleh hasil pencapaian terendah yaitu 20\% anak memiliki keterampilan saintifik Berkembang Sangat Baik (BSB), dan pencapian tertinggi $80 \%$ anak memiliki keterampilan saintifik Berkembang Sesuai Harapan (BSH). Maka rata-rata keterampilan saintifik anak kelompok A pada permainan sains yaitu cukup baik atau Berkembang Sesuai Harapan (BSH). 
DAFTAR PUSTAKA

Agustin, Mubiar. (2017). Mengajar Yang Menyenangkan dan Bermakna Bagi Anak Kiat Sukses Menyiapkan, Membuka, Menyampaikan Inti \& Menutup Pembelajaran. Bandung : CV. Edena Ciptawira Mandiri.

Creswell, J. (2013). Research Design Pendekatan Kualitatif, Kuantitatif, dan Mixed. Yogyakarta : Pustaka Pelajar.

Kementrian Pendidikan dan Kebudayaan RI. (2014). Buku Panduan Pendidik Kurikulum 2013 PAUD Anak Usia 5-6 Tahun. Jakarta: Kemendikbud.

Mukhtar Latif, dkk. (2013). Orientasi Baru Pendidikan Anak Usia Dini Teori dan Aplikasi.

Jakarta: PT Fajar Interpratama Mandiri.
Nugraha, Ali. (2005). Pengembangan Pembelajaran Sains Pada Anak Usia Dini. Jakarta : Departemen Pendidikan Nasional.

Peraturan Menteri Pendidikan dan Kebudayaan No. 146 (2014). Tentang Kurikulum 2013 Pendidikan Anak Usia Dini.

Slamet, Suyanto. (2005). Pembelajaran Anak TK. Jakarta: Departemen Pendidikan Nasional.

Sujiono, Yuliani. (2013). Konsep Dasar Pendidikan Anak Usia Dini. Jakarta : Indeks.

Suyadi dan Dahlia. (2014). Implementasi dan Inovasi Kurikulum PAUD 2013. Bandung: PT Remaja Rosdakarya Offset.

Undang-Undang RI No. 20 Tahun 2003 tentang Sistem Pendidikan Nasional. 